\title{
Large-scale environmental policy change: analysis of the Brazilian reality
}

\section{Mauro Guilherme Maidana Capelari 1}

Suely Mara Vaz Guimarães de Araújo 23

Paulo Carlos Du Pin Calmon 3

Benilson Borinelli 4

1 Universidade de Brasília / Center for Sustainable Development, Brasília / DF - Brazil

2 Universidade de Brasília / Braziliense Institute of Public Law, Brasília / DF - Brazil

3 Universidade de Brasília / Institute of Political Science, Brasília / DF - Brazil

${ }^{4}$ Universidade Estadual de Londrina / Department of Administration, Londrina / PR - Brazil

The Brazilian presidential elections of 2018 brought large-scale changes in the Brazilian environmental policy subsystem. The purpose of this article is to analyze these changes through the lenses of the Advocacy Coalition Framework - ACF. First, we introduced some of the main characteristics of this subsystem, then we presented a hemerographic analysis to describe and analyze the effects of four recent shocks in this subsystem. Two of these shocks were external: (i) the election of a new political elite in power that brought a clear discourse of denial of the relevance of environmental policy and (ii) calamitous environmental events that occurred in Brazil in 2019. The other two shocks were internal: (i) the capture of key positions and resources by dominant coalition members and (ii) the rise of conflict and polarization among the coalitions in the subsystem. The results showed: (i) the rise of a hyper-adversarial environmental policy subsystem; (ii) a realignment between non-dominant coalitions in a cooperative direction; (iii) the imposition of clear barriers to negotiation; (iv) changes in the use of scientific information by more politicized discourses with a high degree of bias. The article contributes to the understanding of the processes of institutional change in environmental policy, especially in contexts of large-scale change generated by increasing electoral polarization and fierce political disputes. It also contributes to the analysis of the limits and possibilities of the ACF in the Brazilian environmental agenda.

Keywords: environmental policy; policy change; advocacy coalition framework; Brazilian politics.

\section{Mudança de larga escala na política ambiental: análise da realidade brasileira}

As eleições presidenciais brasileiras de 2018 trouxeram mudanças em larga escala no subsistema de política ambiental do país. O objetivo deste artigo é analisar essas mudanças através do Advocacy Coalition Framework - ACF. Para isso, introduzimos algumas das principais características do subsistema de política ambiental e, a seguir, apresentamos uma análise hemerográfica para descrever e analisar os efeitos de quatro choques recentes no subsistema em análise. Dois desses choques foram externos: (i) a ascensão ao poder de uma nova elite política que trouxe um discurso claro de negação da relevância da política ambiental e (ii) eventos ambientais calamitosos que ocorreram no Brasil em 2019. Dois outros choques foram internos: (i) a captura de posições e recursos importantes pelos membros da coalizão dominante e (ii) o surgimento de conflitos e polarizações entre as coalizões no subsistema. Os resultados mostraram: (i) a ascensão de um subsistema hiper-contraditório; (ii) o realinhamento entre coalizões não dominantes em direção à cooperação; (iii) a imposição de barreiras claras à negociação; e (iv) mudanças no uso da informação científica por discursos mais politizados com alto grau de viés. O artigo contribui para a compreensão dos processos de mudança institucional na política ambiental, especialmente em contextos de mudança em larga escala gerados pelo aumento da polarização eleitoral e intensas disputas políticas. Contribui também para a análise dos limites e possibilidades do ACF na agenda ambiental brasileira.

Palavras-chave: política ambiental; mudança política; advocacy coalition framework; política brasileira. 


\section{Cambio de gran escala en la política ambiental: análisis de la realidad brasileña}

Las elecciones presidenciales brasileñas de 2018 introdujeron cambios de gran escala en el subsistema de política ambiental del país. El propósito de este documento es analizar estos cambios a través de las lentes del Advocacy Coalition Framework - ACF. Para ello, exponemos algunas de las características principales de este subsistema y, luego, presentamos un análisis hemerográfico para describir y analizar los efectos de cuatro shocks recientes en este subsistema. Dos de estos shocks fueron externos: (i) el ascenso de una nueva élite política al poder, la cual ha traído un claro discurso de negación de la relevancia de la política ambiental y (ii) catastróficos eventos ambientales que ocurrieron en Brasil durante 2019. Otros dos shocks fueron internos: (i) la captura de posiciones y recursos claves por los miembros de la coalición dominante y (ii) el surgimiento de conflictos y polarizaciones entre las coaliciones del subsistema. Los resultados mostraron: (i) el ascenso de un subsistema de política ambiental hipercontradictorio; (ii) el realineamiento de las coaliciones no dominantes en una dirección cooperativa; (iii) la imposición de claras barreras en los procesos de negociación; y (iv) cambios en el uso de información científica por discursos más politizados con un alto grado de sesgo. Este artículo contribuye a la comprensión de los procesos de cambio institucional en la política ambiental, especialmente en contextos de cambios de gran escala generados por un aumento en la polarización electoral e intensas disputas políticas. También contribuye al análisis de los límites y posibilidades del ACF en la agenda ambiental brasileña.

Palabras clave: política ambiental; cambio de políticas; advocacy coalition framework; política brasileña.

\section{INTRODUCTION}

Brazil is the fifth largest country in the world, with seven very different biomes and around $20 \%$ of the world's biological diversity, including almost 2/3 of the Amazon Forest. The country has the largest amount of fresh water in the world, the greatest number of isolated indigenous people, and has been an important player in climate global governance. Therefore, Brazilian environmental policy should be a strategic concern not only for the country, but also for the world (Rochedo et al., 2018).

The environmental policy subsystem in Brazil is complex and has changed considerably in the last thirty years. Despite ongoing tensions, competitions and major weaknesses in implementation, the country has put in place an important administrative and legal structure for protecting natural resources (Viola \& Franchini, 2017).

Although little time has passed, Jair Bolsonaro government has been driving profound and unprecedented changes in the conduct of Brazilian environmental policy subsystem since January 2019. A large-scale change has been occurring starting due to the election of an extremely conservative government, that radically shifted the official policy narrative as well as the distribution of political resources (Hunter \& Power, 2019). The Brazilian environmental subsystem is totally destabilized (Meeus, 2019) with recent incidents such as environmental disasters and increased deforestation.

Advocacy Coalition Framework - ACF is one of the most used frameworks to explain changes in public policies with a high degree of competition and rivalry (Weible \& Ingold, 2018). With relevant applications in Brazil (Carvalho, 2001; A. Soares, 2016; Souza \& Secchi, 2014), ACF stands out with regards to applications in environmental policy (Capelari, Araújo, \& Calmon, 2015; Weible, Heikkila, Ingold, \& Fischer, 2016).

The purpose of this paper is to analyze the recent changes and the new equilibrium between coalitions in the Brazilian environmental policy subsystem from ACF perspective and categories. 
The paper questions were how can we understand the recent large-scale change of Brazilian environmental policy applying ACF? What are the possibilities and limits of this framework in this sense?

We conducted an exploratory study, applying qualitative content analysis to data obtained through a hemerographic survey (newspaper material) between January 2019 and January 2020. The hemerographic analysis has given empirically support to changes in the balance of the Brazilian environmental policy subsystem. For the description of this federal subsystem, we adopted the configuration of environmental advocacy coalitions presented by Araújo (2013).

Therefore, the paper contributes to the understanding of reasons and forms in which the changes in the recent Brazilian environmental policy subsystem occurred and to examine the viability of applying ACF to analyze large-scale change in the balance of a policy subsystem in a country with unconsolidated democracy.

The paper presents a theoretical review of the ACF in the next section. Then, the environmental policy subsystem will be presented. In the fourth section, we argue for the existence of four large-scale changes (shocks) started in 2019 in Brazilian environmental policy subsystem. In the fifth section we analyze the effects of these shocks on the dynamics of the subsystem by ACF perspectives. Finally, the final consideration presents some topics for reflection about the new dynamics in Brazilian environmental policy subsystem.

\section{ACF OVERVIEW}

The Advocacy Coalition Framework - ACF was presented as a framework capable of providing an alternative to traditional approaches to public policy analysis (Sabatier, 1988; Sabatier \& Jenkins-Smith, 1993, 1999). Its aim was to shift the analysis of the policy process from a linear and procedural perspective to an approach anchored in change, its causes, and its effects (Weible \& Ingold, 2018).

ACF interest groups are known as advocacy coalitions (Weible, Ingold, Nohrstedt, Henry, \& Jenkins-Smith). This framework of association produces informal alliances on public policy issues, and its members are united by sharing a set of beliefs that guide how they observe the world and how public policies should be shaped. Broadening the classical idea of interest groups (Baumgartner \& Leech, 1998), advocacy coalition may be presented not only in the legislative power, but in different arenas that include government decision-making process, and may include elected, appointed and administrative government officials, scientists and consultants, representatives of private and non-profit organizations, and the media. Accordingly, by proposing a broader set of actors that influence the political process, the concept of iron triangles is expanded (Sabatier \& Jenkins-Smith, 1993) to a perspective of policy networks (Bonafont, 2004).

Ideological and belief differences are best understood by a three-level belief system. The most deep-rooted beliefs, deep core beliefs, are those that guide the actors' worldview based on normative guidelines with a low volatile profile. More volatile than the deep core, the policy core deals with normative and empirical perspectives, directed to the public policies that make up the subsystem, not being restricted to worldviews, but also to how to transform these views into concrete actions. 
Secondary level or secondary beliefs are less rooted and, therefore, are more likely to change. They concern the willingness to choose public policy instruments capable of solving problems and achieving goals (Weible \& Ingold, 2018).

One of the central objectives of ACF is to investigate changes and stability in public policies, contributing for the understanding of their nature and causes (Jenkins-Smith, Nohrstedt, Weible, \& Ingold, 2018). From ACF's perspective, political changes are understood by the changes they can promote in belief systems. In other words, when policy core beliefs are affected and change at some extent, it is likely that the change in public policy has been drastic. In contrast, changes only occurring in secondary beliefs indicate less abrupt changes. In this sense, policy-oriented beliefs were formed from the criterion of susceptibility to change, which makes them important elements to identify and characterize the changes (Sabatier, 1988).

ACF offers four conceptual pathways for promoting changes in public policy. The first is related to external sources. Derived from external subsystem events or relatively stable parameters, ACF assumes that changes in the policy subsystem occur due to external shocks, disturbances that are beyond the control of the actors involved in the subsystem, crises, disasters or changes in socioeconomic conditions and political regimes (Sabatier \& Weible, 2007). The second path to political change occurs through the influence of internal events. Examples of internal events are conflicts within and between coalitions, political scandals, and failed ideas that influence the rethinking of beliefs and convictions of actors from new views about the problem, its causes, and implications (Nohrstedt \& Weible, 2010; Sabatier \& Weible, 2007).

The negotiated agreements represent the third pathway for political change under ACF's view. Such agreements are usually made by collaborative institutions, which lead the negotiation process and facilitate agreements between coalitions (Jenkins-Smith, Nohrstedt, Weible, \& Ingold, 2018). The fourth path of political change is long-term oriented and represented by policy-oriented learning. ACF defines policy-oriented learning as "enduring alternations of thought or behavioral intentions that result from experience and which are concerned with the attainment or revision of the precepts of the belief system of individuals or of collectives" (Sabatier \& Jenkins-Smith, 1993, p. 42).

The empirical studies of the ACF have added secondary components to understand political changes. Twelve secondary components have been added to understand policy changes in public policy process: (i) new dominant coalition, (ii) change in the distribution of resources, (iii) venue opening or closing, (iv) minority coalition mobilization, (v) dominant coalition belief change, (vi) minority coalition belief changes, (vii) dominant coalition belief confirmation, (viii) minority coalition belief confirmation, (ix) dominant coalition strategy change, (x) minority coalition strategy change, (xi) a hurting stalemate, and (xii) presence of a policy broker (Pierce, Peterson, \& Hicks, 2020).

Focusing on policy change and conceptual pathways for promoting changes, the next section will describe the composition of the environmental policy subsystem in Brazil. 


\section{ENVIRONMENTAL POLICY SUBSYSTEM IN BRAZIL: A SHORT REVIEW}

Environmental policies are generally characterized by a high degree of complexity and conflict (Caldwell, 1993). They encompass a large number of socio-environmental problems and phenomena that interact at multiple time and space scales, such as pollution, climate change, deforestation, and reduction of biodiversity.

As it seeks to promote sustainability in socio-environmental interactions, environmental policy permeates, questions and mobilizes a large number of areas of knowledge, ideologies, beliefs, actors, geographical boundaries, human activities, economic sectors and public policy subsystems. If there is a consensus that environmental policy can be recognized for being a regulatory system, an administrative apparatus, a body of ideas, beliefs and specialized knowledge, and a place of contestation and decision, what should governments do has been a continuous focus of discussion and scientific and political dispute (Duit, Feindt, \& Meadowcroft, 2016).

A controversial and recurring issue is the restrictions of environmental regulation to economic growth, for example, by preventing or limiting access to natural resources, and imposing the internalization of costs. Responses to this and other controversies originated in different positions and beliefs on what should be sustainability, environmental justice and what is the role of the State in the protection and distribution of natural resources (Hopwood, Mellor, \& O'Brien, 2005). These positions and beliefs will be incorporated by political coalitions that try to influence decisions in the Brazilian environmental policy subsystem.

Araújo (2013) is one of the most complete applications of ACF in Brazilian environmental policy. The study is based on an extensive and detailed analysis of Congressional hearings related to major decisions affecting the Brazilian environmental subsystem between 1992 and 2012. It detected the presence of four main advocacy coalitions influencing the so-called "green agenda" in Brazil, namely (Box 1):

BOX 1

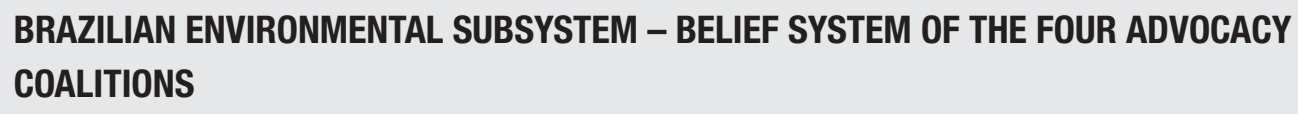

\begin{tabular}{|c|c|c|c|}
\hline Enlightened technocrats & Socio-environmentalists & Modern developmentalists & Traditional developmentalists \\
\hline $\begin{array}{c}\text { Priority for the preservation of } \\
\text { natural resources }\end{array}$ & $\begin{array}{l}\text { Focus on reconciling } \\
\text { sustainable use and }\end{array}$ & $\begin{array}{l}\text { Focus on the sustainable } \\
\text { use of natural resources }\end{array}$ & $\begin{array}{l}\text { Views on natural resources } \\
\text { tending to utilitarianism }\end{array}$ \\
\hline $\begin{array}{c}\text { Defense of a State } \\
\text { characterized more by its } \\
\text { vigorous action than by its } \\
\text { democratic aspects }\end{array}$ & $\begin{array}{l}\text { preservation } \\
\text { Emphasis on democratic } \\
\text { and participatory processes }\end{array}$ & $\begin{array}{c}\text { Defense of the minimum } \\
\text { state }\end{array}$ & $\begin{array}{l}\text { Defense of a State with } \\
\text { a strong presence in the } \\
\text { promotion of private initiatives }\end{array}$ \\
\hline
\end{tabular}




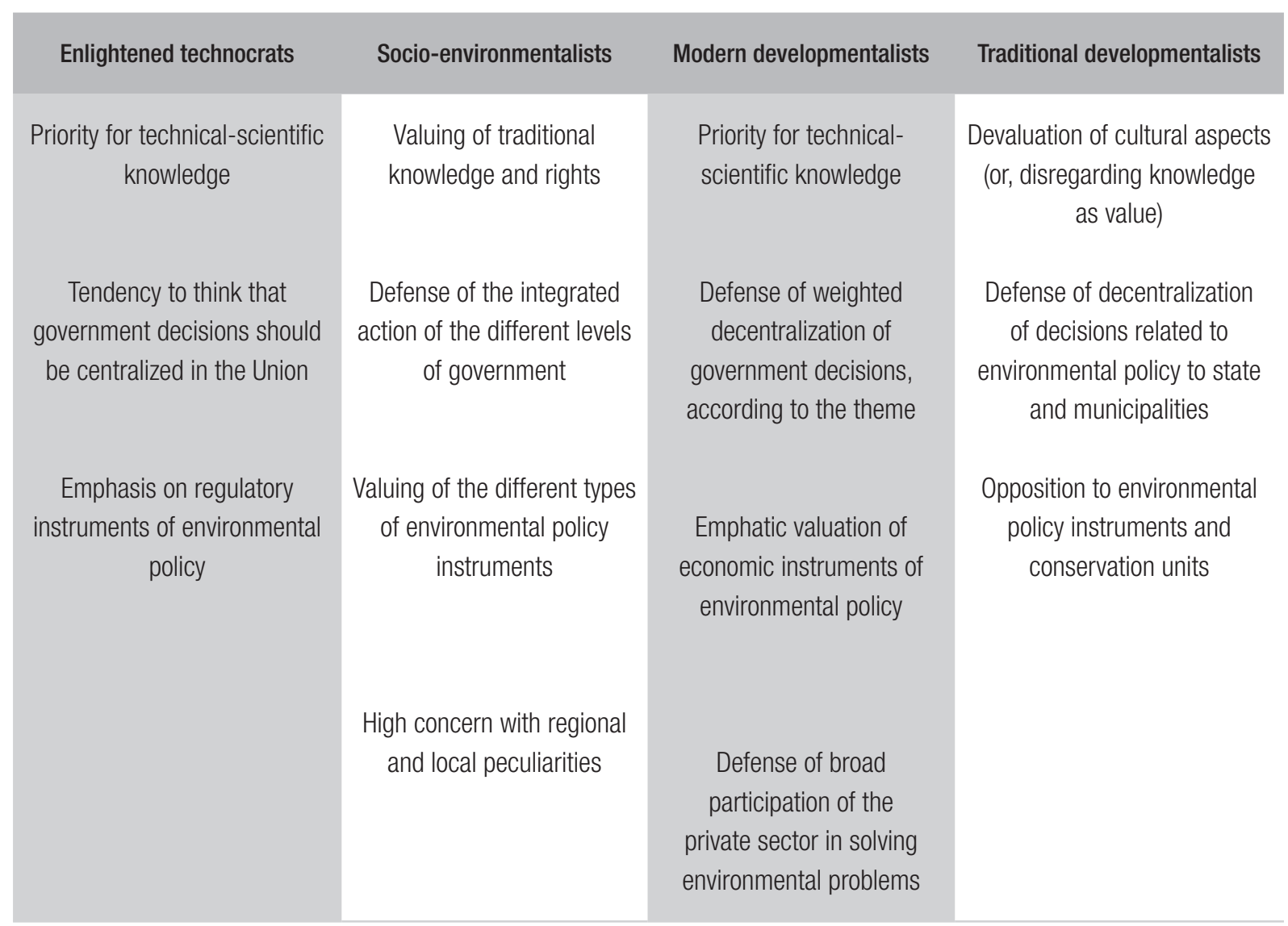

Source: Araújo (2013).

The Traditional Developmentalists, dominant advocacy coalition in recent Brazilian environmental policy subsystem, is successor to a legacy of the agribusiness-export model sustained, at least since the time when Brazil was a colony of Portugal, in the concentration of land (natural resources), in slave labor and in political conservatism. With the country's urbanization and industrialization, large coffee producers in the First Republic, for example, lost influence in the conduct of State policies, but they remained an important political and economic force. At the present time, powerful complexes that produce agricultural commodities (for example, meats, soy, wood and sugar) and minerals (iron, bauxite, manganese and niobium) have prominent positions in this coalition, made up of national and multinational capitals (Pádua, 2018).

Traditional Developmentalists were one of the main integrators of a neo-conservative and neoliberal movement that won in the 2018 presidential elections. Internally, this movement brings together, in addition to agribusiness, an expressive representation of the military, evangelicals, powerful businessmen who shared beliefs, such as anti-leftism, authoritarianism, reducing state intervention and social policies, and opening the market. Externally, the dominant coalition benefited and aligned itself with the neoconservative wave led by US President (Hunter \& Power, 2019). The Traditional Developmentalists have always pressed for weak regulation and implementation of environmental legislation, especially federal ones (Dean, 1997). 
International pressure, public opinion and socio-environmental movements contributed, in a context of re-democratization, to the expanding the institutional structure, to the "flood" of environmental legislation (Dryzek, 1992), as well as to organize the three others coalitions in the Brazilian environmental policy subsystem (Enlightened Technocrats, Socio-Environmentalists and Modern Developmentalists) (Hochstetler \& Keck, 2007).

Advances in Brazilian environmental policy have generated permanent and growing conflicts and tensions between the environmental policy subsystem and the productive sectors and other subsystems responsible for economic expansion, such as agriculture, infrastructure, industry and others (Ames, 2019).

The counteroffensive of the current Traditional Developmentalists coalition intensified since 2008, demanding the relaxation of important regulatory legislations: environmental licensing, the Federal Forest Law (1965), authorization of pesticides, reduction of indigenous lands and other protected areas. The main milestone and victory of this counteroffensive was the Federal Forest Law reform in 2012 (Law 12.651/2012), which, despite contrary arguments from scientific and experts, increased the productive use of protected areas and amnestied fines for deforestation (B. Soares et al., 2014).

With the rise of Jair Bolsonaro, the Traditional Developmentalists coalition - the current dominant coalition in Brazilian environmental subsystem -, started to occupy strategic spaces in the economic and environmental policy sectors in the federal government, to start a phase that can already be characterized as the one of the most explicit dismantling of the federal environmental policy, increasing tensions with specialists, public opinion and environmental movements.

We will assume, for the purpose of analyzing policy changes from the ACF perspective, that the four coalitions addressed in Box 1 are representative of the subsystem of Brazilian environmental policy even after the recent large-scale changes, presented in greater details in the next section.

\section{ENVIRONMENTAL POLICY IN BRAZIL: RECENT CHANGES (SHOCKS) FROM THE ACF PERSPECTIVE}

Brazil's environmental policy subsystem underwent significant large-scale changes in 2019. We will highlight such changes, from the "shock category" proposed by the ACF. The discussion will focus on external and internal shocks concerning the subsystem.

Recent internal shocks are related to two aspects: (i) growth in the power resource of the dominant coalition (Traditional Developmentalists) and the (ii) lack of structural influence in the subsystem by this coalition.

(i) The political resources of Traditional Developmentalists were enhanced after the election of 2018. Several factors explain this expansion: the first was the increase in the number of seats controlled by the Rural Caucus ("Bancada Ruralista") in the National Congress. The share of the seats controlled by the "Ruralistas" jumped to $44 \%$ of the seats at the Lower House and $39.5 \%$ of the seats at the Federal Senate (Congresso Em Foco, 2019a). This increased political influence was sufficient, for example, to restore the Special Congressional Committee on Climate Change and, immediately after, to appoint as president of this committee someone who does not believe in the urgency of measures targeted to mitigate the effects of climate change (Shalders, 2019).

In addition to a new distribution of seats in the Congress there were also important changes in the Executive Branch which strengthen the discourse and values of the Traditional 
Developmentalists coalition. The new President and his political appointees were outspoken critics of the previous environmental policies and institutions, and denounced the political groups associated with the environmental movement as opportunist and corrupt without any explicit proof. The President is against most of the existing environmental regulations and frequently denounces the existing environmental agencies as an "industry of environmental fines" (Dunder, 2019) that inhibits investment and economic growth. In addition to that, he and his ministries criticized the number and size of the existing Indigenous lands and environmental conservation units in the country (Carta Capital, 2018), and announced the intent to reform current laws on these subjects.

In addition to an expansion in the number of seats in Congress and political appointees in the Executive Branch, members of the Traditional Developmentalists coalition gained access and control of technical information and have been using it to influence public opinion. We should mention the case of the data provided by Amazon Rainforest Monitoring System that uses remote sensing satellite information to monitor deforestation in the Brazilian Amazon biome, which covers an area of 4.7 million square kilometers. The System is managed by the National Institute for Space Research (Instituto Nacional de Pesquisas Espaciais - INPE). INPE was created in 1971, and currently is a research unit of the Brazilian Ministry of Science and Technology. In August 2019, the chief of the agency was fired by the Ministry of Science and Technology after a public divergence with the President over the validity of the data from the satellite system monitoring deforestation. The President argued that data showing increasing deforestation and fires in the region was altered to attack his government (Congresso Em Foco, 2019b).

(ii) A second internal shock, linked to the increase in the control of power resources of the dominant coalition, has been noted in the environmental policy subsystem and it is a paradoxical movement. On one hand, the Traditional Developmentalists coalition gained control of some of the most valuable resources and strategic positions in the environmental policy subsystem. On the other hand, this coalition's reputation lost strength. The actions of this group began to be more strongly questioned from a technical point of view, including negative effects with buyers of Brazilian products in the international market (Vieira, 2019).

Since early 2019 there has been a huge realignment and a highly contentious dispute between members of the dominant coalition and the members from all other three coalitions (Enlightened Technocrats, Socio-Environmentalists and Modern Developmentalists). A concrete example was the unprecedented construction of a front composed of eight former environment ministers to subscribe an open letter of protest warning about the "systematic, constant, and deliberate policy of deconstruction and destruction of environmental policies" (Gortázar, 2019). Another example was the open letter of protest directed to the Minister of Environment by the National Association of Environmental Careers (Associação Nacional de Servidores de Carreira de Meio Ambiente - Ascema Nacional), who they called "cunning, fallacious, and rude" after he publicly threatened to investigate the conduct of environmental agents of the Brazilian Environmental Agency (Calcagno, 2019). In the same line, a group of non-governmental organizations organized offensives against the government's management framework that they call "environmental anti-politics" (Girardi, 2019).

With regard to external shocks, at least two are worth highlighting: (i) important changes in ideological orientation at the federal Executive Branch, characterized by authoritarianism and 
strong commitment to economic liberalization and disregard for environmental impacts; (ii) and the environmental disasters that occurred in Brazil.

(i) The rise of a new political elite, nowadays in the role of dominant coalition in environmental policy subsystem, brought changes also in economic and regulation policies, with a strong emphasis on liberalization and privatization and the dismantling of the so-called "Administrative State". These changes have also affected the many aspects of the environmental subsystem. The privatization profile was observed in the management of national parks (NexoJornal, 2019), in the reduction of the environmental fines to enable the participation of private companies (Prizibisczki, 2019) and in the defense of liberalization of mining and agricultural activities in the Amazon Rainforest Region and Indigenous lands (Vilela, 2019). Moreover, these changes are also observed in the intention of hiring private companies to monitor the deforestation of the Amazon $(\mathrm{G1}, 2019)$ and important changes in the current regulation framework in order to create incentives for water privatization allowing private companies to control water provision and sanitation services in Brazilian municipalities (Pupo, 2019).

Meanwhile, there were movements in the dominant coalition towards demobilization and inhibiting popular participation in public policy decisions. The presidential discourse shows clearly the government's discomfort with the participation of NGOs in the political process (Pereira, 2019). Public officials blamed NGOs first for the increase in the number of fires in the Amazon forest (Mazui, 2019b), and then for the oil spills on the Brazilian coast (Moreira, 2019). The interruption of the Amazon Fund financing ${ }^{1}$ in 2019 (Figueiredo, 2019b) was largely due to the Ministry of the Environment's suspicion of the existence of inconsistencies in NGOs' contracts (Figueiredo, 2019a) - which was contradicted moments later by the international financiers (Trigueiro, 2019).

In addition to the troubled relationship with the third sector, there have been a movement to reduce the participation of civil society in political processes. This movement claimed for the downsizing of the National Environmental Council (B. Soares, 2019), which in practice would make the operation of this collegiate body through technical chambers unfeasible, as well as the extinction of many collegiate committees that assist in Brazil's environmental management (Grandelle, 2019).

(ii) External factors linked to disasters have put pressure on the environmental policy subsystem, with the potential to promote changes. Only in 2019, there were three major environmental disasters in Brazil: the disruption of a dam in the state of Minas Gerais (MG); forest deforestation and fires in the Amazon Rainforest; and the appearance of oil spill on the Northeastern shore.

The collapse and disruption of dam B1 at the Córrego do Feijão Mine in Brumadinho (MG), was considered a major environmental disaster, with more than 270 deaths (Cordeiro, 2019). The Corrego do Feijão Mine was managed by the multinational mining company Vale S.A. Once a state-owned company, Vale S.A, now operates in thirty countries and is listed in the stock exchanges in São Paulo, New York, Hong Kong, Jakarta, Paris and Madrid. According to the investigations conducted so far, it was a tragedy foretold, because Vale S.A. knew that the dam was unstable months before the collapse (Deputados, 2019). Although the federal government responded immediately to help the victims of the disaster, it moved away from monitoring repair and compensation programs, delegating all responsibility in this regard to the state of Minas Gerais (Deputados, 2019).

\footnotetext{
${ }^{1}$ The Amazon Fund is a REDD + mechanism created to raise donations for non-reimbursable investments in efforts to prevent, monitor and combat deforestation. For more detail, see: http://www.fundoamazonia.gov.br/en/home/
} 
Beyond the 30\% increase in Amazon deforestation (Oliveira \& Matos, 2020), the year 2019 had record numbers of fire spots in the Amazon Rainforest (O Globo, 2019). In addition to the Amazon deforestation and fires, the way the federal government treated this problem generated countless criticisms from the scientific and environmental communities, and strong criticism from the three non-dominant coalitions of the subsystem. The Minister of the Environment, for example, said that the association between forest fires and the climate in the city of São Paulo was fake news (Toledo, 2019), indicated problems in the actions promoted by state governments to contain the outbreaks of fire (Turollo \& Fernandes, 2019) and said that the outbreaks increased because the region was going through a dry period (TV Cultura, 2019), a fact that is not proven by scientific data (Marés, Moraes, \& Afonso, 2019). The President claimed that the forest was not on fire, but rather the pasture areas (Mazui, 2019a), a fact also denied by national and international researchers (Mendes, 2019).

The presence of oil spills on the beaches of Northeastern Brazil has been considered the largest environmental aggression ever suffered by the country, similar to the Gulf of Mexico spill in 2010 (Valor Online, 2019). As in the case of the fires, the attention was not only on the disaster but on the weak governmental action for its containment. There was strong criticism of the federal government for the delay in promoting actions to mitigate the disaster. The Federal Public Prosecutor's Office has filed a lawsuit against the Union (Deutsche Welle [DW], 2019), a Committee of Inquiry was created in the Federal Senate (Madeiro, 2019) and another was created in the House of Representatives (Vivas, 2019) to investigate the State's omission to act on the tragedy. Surrounded by criticism, the Environment Minister blamed the neighboring country Venezuela (Agência Brasil, 2019) and Greenpeace (Barbosa, 2019) for the disaster.

In the next section, we will discuss the four shocks impact on the environmental policy subsystem according to ACF framework perspective.

\section{POLICY CHANGE: THEORETICAL DISCUSSION ABOUT RECENT BRAZILIAN ENVIRONMENTAL POLICY SHOCKS}

It is not easy to analyze recent large-scale changes in Brazilian environmental policy by the inconclusive nature of the events and their effects on the structure of the environmental subsystem. The 2018 election brought to power a Traditional Developmentalist coalition, altering the balance of the environmental subsystem and creating a new dynamic for policy change. In short, we will analyze four major implications in ACF theoretical debate: (i) the rise of a hyper-adversarial environmental policy subsystem; (ii) a realignment between non-dominant coalitions in cooperative direction; (iii) the imposition of clear barriers to negotiation; and (iv) changes in the use of scientific information by more politicized discourses with a high degree of biases.

(i) The rise of a hyper-adversarial environmental policy subsystem. The capacity of political actors to produce and shape the results of public policies is influenced by how the actor is perceived by their peers in the decision-making process. The power of decision-makers is critical to the outcomes and legitimacy of the policy, and is related to at least two criteria: their reputation or structural influence and their formal authority or institutional influence (Ingold \& Leifeld, 2014).

The previous section shows the low level of reputation of the dominant coalition among the actors belonging to the environmental policy subsystem in Brazil. The meeting of eight former ministers of 
the environment in a speech contrary to what is practiced by the current Environmental Minister, the critique produced by the National Association of Environmental Careers and by NGOs, are concrete examples of the dominant coalition's lack of reputation influence. The criticism are so widespread that they often generate mockery on social network presenting the Minister of the Environmental as an anti-minister (O Globo, 2019d).

The reputational deficiency of the dominant coalition in the subsystem negatively impact the effectiveness and legitimacy of decision-making in the public sector (Watkins \& Rosegrant, 1996). Added to this, there is also the authoritarian and often revanchist style of the dominant coalition that has fomented polarization and the rise of conflict in a political subsystem already characterized by intense disputes (Muta, 2019).

In this sense, conflicts become the rule and not the exception in environmental policy in Brazil, which appears to have overcome the adversarial contour towards a hyper-adversarial policy subsystem. A conflictive and hyper-adversarial policy subsystem could create a divergence in policy position and cross-coalition coordination, reduce negotiation venues (Weible, Heikkila, \& Pierce, 2018), and expand the threats and the unwillingness between coalitions (Heikkila \& Weible, 2017).

The Brazilian environmental policy subsystem could be a great example to test hypotheses and improve some research agendas on policy conflict. ACF studies pay limited attention to conflict and hyper-adversarial subsystems, as well as to the implications in terms of policy change (Weible \& Heikkila, 2017).

(ii) A realignment between non-dominant coalitions in a cooperative direction. While the dominant coalition has reputation fragilities in the Brazilian environmental policy subsystem, it has formal authority or institutional influence (Ingold \& Leifeld, 2014). Formal authority allows a dominant coalition to access political resources, to increase political influence in National Congress and to alter structures and public agents according to their particular interest (Spring, 2020b). Hence, a dominant coalition frequently imposes their beliefs and ideas on environmental policy, even without the support or agreement of the other three advocacy coalitions that act in the subsystem.

In response to this scenario, the three other non-dominant advocacy coalitions (Enlightened Technocrats, Socio-Environmentalists, and Modern Developmentalists) start a cooperation realignment between them in opposition to the dominant coalition and, more than that, against the narrative of the President and his allies about environmental policy. This unprecedented realignment among environmentalists that have different points of view makes explicit a clear effort by non-dominant coalitions in order to (re)build new channels of articulation and negotiation (Adshead, 2011; Sabatier \& Jenkins-Smith, 1993). With the union of the three groups, without yet mischaracterizing their differences in policy beliefs, they escalate a conflict that has been raging since January 2019.

Additionally, the recent realignment between non-dominant coalitions represents a movement towards policy-oriented learning in the Brazilian environmental policy subsystem (Moyson, 2017). This learning process involves reducing differences between these three coalitions in favor of reducing conflict in the environmental policy subsystem. The signals for cooperation indicate that an effort towards lower losses to the environmental institutions in Brazil depends on a negotiated agreement around a positive environmental agenda, capable of competing against the narrative and formal power of the dominant coalition agenda. 
Whether this cooperation movement between the three non-dominant coalition is related to the "Devil Shift" ACF category (Sabatier, Hunter, \& McLaughlin, 1987), to recurring environmental disasters, or to an increase in the convergence of policy beliefs between the rival and non-dominant coalitions (Jenkins-Smith, Nohrstedt, Weible, \& Sabatier, 2014; Kettell \& Cairney, 2010; Weible \& Sabatier, 2009), are relevant questions to be tested in future research.

(iii) Imposition of clear barriers to negotiation. The downsizing of the National Environmental Council represents a clear example of this barrier as well as public speech from the dominant coalition against the NGO's, science data and transparency in environmental public service, all shown in the previous section. This movement that reinforces a deadlock profile in the Brazilian environmental policy subsystem (Sabatier \& Weible, 2007) was discussed in some other empirical cases (Frahsa, Rütten, Abu-Omar, \& Schow, 2014; Heikkila et al., 2014).

After taking over the formal authority in Brazilian environmental subsystem, the Traditional Developmentalists coalition appears to have no intention to create negotiation venues and agreement with the other three non-dominant coalitions. Instead, the dominant coalition has been preferring to impose unilateral decisions or to negotiate with coalitions belonging to other subsystems (agriculture, mining and military). This kind of behavior induces a reflection about the study of "dialogue of deaf" (Sabatier, 1988) that is still little discussed in ACF empirical cases.

A barrier imposed by the dominant coalition in the Brazilian environmental subsystem suggested an important reduction in the influence by civil society and specialized actors in generating and changing policies. As mentioned previously, one of the most important ACF frameworks' ideas is the expansion of the number of actors involved in the public policy subsystem to beyond the "iron triangle" (Weible \& Sabatier, 2009). The political closure to civil society participation that is currently taking place in the Brazilian environmental subsystem goes against the consolidation of a wide and specialized network of actors. This ambiguity could generate a discussion on the adherence of ACF in a non-consolidated pluralism (John, 2003) outside Western Europe and North America (Henry, Ingold, Nohrstedt, \& Weible, 2014), as well as about the ability of marginalized groups to influence policy process (Holmes \& Scoones, 2001), especially in socially unequal countries like Brazil (Souza, 2004).

Furthermore, by prioritizing the medium and micro level institutional analysis, the ACF does not focus on the macro-structural or historical plan (Ianoni, 2017) which, in the case of Brazil, implies disregarding or marginalizing the legacy of an extractive and agriculture-export economic structure and its historically complicated relationship with environmental protection.

(iv) Changes in the use of scientific information by more politicized discourses with a high degree of biases. These changes have been discussed in the previous section when the dominant coalition put in doubt the numbers of Amazon deforestation, fired INPE's president, accused inconsistencies in the contract with the Amazon Fund and NGOs, blamed NGOs first for the increase in the number of fires in the Amazon forest for the oil spills in the Brazilian coast. A lack of concern with the use of scientific basis in narratives is consolidated, which did not occur, at least not to this degree, before 2019.

This movement, produced by the dominant coalition, represents a strategy for information deconstruction and, hence, to be able to introduce new beliefs and ideas in public policy process. The use of information by the Traditional Developmentalists coalition often deals with fake news, antiscience, anti-traditional media and environmental crisis denialist t components (Benites, 2018). This 
kind of dominant coalition strategy could be understood with ACF secondary component that explains a policy change in the Brazilian environmental policy subsystem (Pierce, Peterson, \& Hicks, 2020).

The biased information used as dominant coalition strategy has two implications. First, its association with the mobilization of public opinion. As discussed previously, the absence of reputational influence of the dominant coalition within the Brazilian environmental subsystem, even with the strength of formal power, implies a reduction in the legitimacy of the dominant coalition and also hinders its performance in practice (which can even lead to ineffective disaster response as mentioned above). By biasing scientific and official information, the Traditional Developmentalists coalition bets on legitimizing its actions only through public opinion. In ACF perspective, the public opinion is an important coalition resource to increase the power, the capacity of influence and the probability of winning the competition in the subsystem and thus imposing their desires, interests and beliefs on the decision-making process (Weible \& Ingold, 2018).

The second implication concerns the impact of distortions of scientific information in the policy belief system. Although the ACF predicted to some extent biases and political use of information in the subsystem, its studies analyzed their impact on instrumental and policy core beliefs. The form of intervention in the public problem is the main objective of this strategy (Montpetit, 2011). However, in Brazilian environmental policy subsystem, biases and political use of information starts to be applied in the deep core beliefs. This scenario allows dominant coalition to deny environmental public problems like environmental crisis and climate change. The denialist strategy of public environmental problems guarantees the state's inaction (McConnell \& Hart, 2019), inaugurates a more conflicted way of biased use of information and increases the advance of environmental deregulating forces.

In the next section we will develop the final considerations.

\section{FINAL CONSIDERATIONS}

Since re-democratization of Brazil, we have not seen a large-scale change in the environmental policy subsystem, such as the one we are currently seeing. The return to formal power of conservative and liberal ideologies, represented by Traditional Developmentalists, has been promoting changes in environmental policy by a combined effort of dismantling politics and fighting against learning, negotiations, civil society, scientific information, and experts.

In this article, using ACF contributions, we summarize, from the confluence of external and internal shocks to the subsystem, four implications of these changes: the rise of a hyper-adversarial environmental policy subsystem; the realignment between non-dominant coalitions in a cooperative direction; the imposition of barriers to negotiation; and changes in the use of scientific information by more politicized ones with a high degree of biases.

These large-scale changes and its implications challenge the conventional analytical form of the ACF. Although it allows to capture and systematize important features of the changes that have occurred, it is necessary to pay attention to their weaknesses to analyze societies' manifestations by profound and varied inequalities, including access to natural resources. Historically characterized by social inequities, Brazilian reality is becoming increasingly marked by political authoritarianism, which can aggravate this situation. In terms of environmental policy, if the political reality is not 
RAP | Large-scale environmental policy change: analysis of the Brazilian reality

reversed, Brazil is moving towards the perspective of non-public policy and, perhaps, of the dismantling of the policy subsystem.

In addition to the various topics already suggested above, we recommend investigations in:

(i) The hyper-adversarial subsystem and the deep beliefs rupture in the decision-making patterns typical of a liberal democracy could be better explored. In terms of the ACF, is it worth asking what can be learned with a dominant coalition guided by symbolic and even material violence? What learning is possible with a dominant coalition denying the legitimacy of the subsystem's existence?

(ii) Revitalization and articulation of non-dominant coalitions need to be better monitored in hyper-adversarial subsystem. Studying the degree of approximation of the different beliefs of non-dominant coalitions seems to be a way to understand negotiation venues in conflicting subsystems.

(iii) The movement to exclude civil society and experts from the subsystem composes another research agenda. It is necessary to detail the extent of this exclusion and its impacts on policy process. In this effort, correlating with ACF categories such as knowledge, policy learning and negotiated agreements could be important.

(iv) Distortions in scientific data, using tactics like fake news, post-truth and denialism are still not explored by the ACF. As scientific information is an important element to understand policy change in the ACF, its denial, distortion and even devaluation needs to be incorporated in future studies.

Thus, the challenges for the use of ACF in Brazil and developing countries should continue to be investigated, since they have political and social systems and subsystems that put the assumptions foreseen in the ACF framework at stake. 


\section{REFERENCES}

Adshead, M. (2011). An advocacy coalition framework approach to the rise and fall of social partnership. Irish Political Studies, 26(1), 73-93.

Agência Brasil. (2019, October 23). Governo pede na OEA que Venezuela se manifeste sobre óleo, diz Salles. Brasília, DF: Author. Retrieved from http:// agenciabrasil.ebc.com.br/geral/noticia/2019-10/ governo-pede-na-oea-que-venezuela-se-manifestesobre-oleo-diz-salles

Ames, B. (2019). Routledge Handbook of Brazilian Politics. London, UK: Taylor \& Francis Group.

Araújo, S. M. V. G. (2013). Política ambiental no Brasil no período 1992-2012: um estudo comparado das agendas verde e marrom. Brasília, DF: Universidade de Brasília.

Barbosa, M. (2019, October 24). Salles sugere que navio do Greenpeace derramou óleo no Nordeste. Congresso Em Foco. Retrieved from https:// congressoemfoco.uol.com.br/especial/noticias/ salles-sugere-que-navio-do-greenpeace-derramouoleo-no-nordeste/

Baumgartner, F. R., \& Leech, B. L. (1998). Basic interests: The importance of groups in politics and in political science. Princeton, NJ: Princeton University Press.

Benites, A. (2018, September 28). A máquina de 'fake news' nos grupos a favor de Bolsonaro no WhatsApp. El País. Retrieved from https://brasil.elpais.com/ brasil/2018/09/26/politica/1537997311_859341. html

Bonafont, L. C. (2004). Redes de políticas públicas. Madrid, España: Centro de Investigaciones Sociológicas.

Calcagno, L. (2019, April 24). ICMBio, ligado ao Meio Ambiente, perde terceiro chefe em menos de 10 dias. Correio Braziliense. Retrieved from https://www.correiobraziliense.com.br/app/noticia/ politica/2019/04/24/interna_politica,751254/sobtensao-icmbio-perde-terceiro-chefe-em-menos-dedez-dias.shtml

Caldwell, L. K. (1993). Environmental policy as a political problem. Review of Policy Research, 12(3-4), 104-117.
Capelari, M. G. M., Araújo, S. M. V. G., \& Calmon, P. C. (2015). Advocacy Coalition Framework: um balanço das pesquisas nacionais. Administração Pública e Gestão Social, 7(2), 91-99.

Carta Capital. (2018, October 26). As ameaças de Bolsonaro ao papel central do Brasil no meio ambiente. São Paulo, SP: Author. Retrieved from https://www. cartacapital.com.br/politica/bolsonaro-ameaca-alideranca-do-brasil-em-questoes-ambientais/

Carvalho, G. O. (2001). Metallurgical Development in the Caraja' s Area: A Case Study of the Evolution of Environmental Policy Formation in Brazil. Society \& Natural Resources, 14(2), 127-143.

Congresso Em Foco. (2019a, April 02). Com 257 parlamentares, bancada ruralista declara apoio à reforma da Previdência. Brasília, DF: Author. Retrieved from https://congressoemfoco.uol.com. br/economia/com-257-parlamentares-bancadaruralista-declara-apoio-a-reforma-da-previdencia/

Congresso Em Foco. (2019b, August 02). Diretor do Inpe é demitido após desafiar Bolsonaro. Brasília, DF: Author. Retrieved from https://congressoemfoco. uol.com.br/meio-ambiente/diretor-do-inpe-edemitido-apos-desafiar-bolsonaro/

Cordeiro, F. (2019, November 20). No 300 dia de buscas, bombeiros encontram mais um corpo em Brumadinho. Estadão. Retrieved from https:// brasil.estadao.com.br/noticias/geral,no-300-dia-debuscas-bombeiros-encontram-mais-um-corpo-embrumadinho,70003096451

Dean, W. (1997). A Ferro e fogo: a história da devastação da mata atlântica brasileira. Rio de Janeiro, RJ: Companhia das Letras.

Deputados, C. (2019). Comissão Parlamentar de Inquérito: rompimento da barragem e Brumadinho (relatório final da CPI). Brasília, DF: Câmara dos Deputados

Deutsche Welle. (2019, October 19). MPF entra com ação contra União por omissão sobre manchas de óleo. Bonn, Germany: Author. Retrieved from https://www.dw.com/pt-br/mpf-entra-com-açãocontra-união-por-omissão-sobre-manchas-deóleo/a-50894882

Dryzek, J. S. (1992). Ecology and discursive democracy: Beyond liberal capitalism and the administrative state. Capitalism Nature Socialism, 3(2), 18-42. 
Duit, A., Feindt, P. H., \& Meadowcroft, J. (2016). Greening Leviathan: the rise of the environmental state? Environmental politics, 25(1), 1-23.

Dunder, K. (2018, December 01). Bolsonaro afirma que "farra das multas" ambientais vai acabar. $R 7$. Retrieved from https://noticias.r7.com/brasil/ bolsonaro-afirma-que-farra-das-multas-ambientaisvai-acabar-01122018

Figueiredo, P. (2019a, May 17). Ministro do Meio Ambiente diz ter analisado $1 / 4$ dos contratos do Fundo Amazônia e verificado inconsistências. G1. Retrieved from https://g1.globo.com/natureza/ noticia/2019/05/17/ministro-do-meio-ambientediz-ter-analisado-14-dos-contratos-do-fundoamazonia-e-verificado-inconsistencias.ghtml

Figueiredo, P. (2019b, August 12). Fundo Amazônia não aprovou nenhum projeto em 2019. G1. Retrieved from https://g1.globo.com/natureza/ noticia/2019/08/12/estagnado-fundo-amazonianao-aprovou-nenhum-projeto-em-2019.ghtml

Frahsa, A., Rütten, A., Roeger, U., Abu-Omar, K., \& Schow, D. (2014). Enabling the powerful? Participatory action research with local policymakers and professionals for physical activity promotion with women in difficult life situations. Health promotion international, 29(1), 171-184.

Franco, B. M. (2019, April 21). Um antiministro no Meio Ambiente. O Globo. Retrieved from https:// blogs.oglobo.globo.com/bernardo-mello-franco/ post/um-antiministro-no-meio-ambiente.html

Girardi, G. (2019, August 21). ONGs: "Queimadas refletem irresponsabilidade de Bolsonaro". Terra. Retrieved from https://www.terra.com.br/noticias/ ciencia/sustentabilidade/meio-ambiente/ongsqueimadas-refletem-irresponsabilidade-de-bolso naro,f05badec3c96fb46ef5dc5b2b92d5fe1pty35u hy.html

G1. (2019, August 21). Ibama lança edital para contratar empresa privada para monitorar desmatamento na Amazônia. Retrieved from https:// g1.globo.com/natureza/noticia/2019/08/21/ibamalanca-edital-para-contratar-empresa-privada-paramonitorar-desmatamento-na-amazonia.ghtml

Gortázar, N. G. (2019, May 08). Uma inédita frente de ex-ministros do Meio Ambiente contra o desmonte de Bolsonaro. El País. Retrieved from https://brasil.elpais.com/brasil/2019/05/08/ politica/1557338026_221578.html

Grandelle, R. (2019, October 26). Governo ignorou nota técnica que pedia recriação de comitês responsáveis por combate ao óleo. $O$ Globo. Retrieved from https://oglobo.globo.com/ sociedade/governo-ignorou-nota-tecnica-quepedia-recriacao-de-comites-responsaveis-porcombate-ao-oleo-1-24043953

Heikkila, T., Pierce, J. J., Gallaher, S., Kagan, J., Crow, D. A., \& Weible, C. M. (2014). Understanding a Period of Policy Change: The Case of Hydraulic Fracturing Disclosure Policy in C olorado. Review of Policy Research, 31(2), 65-87.

Heikkila, T., \& Weible, C. M. (2017). Unpacking the intensity of policy conflict: a study of Colorado's oil and gas subsystem. Policy Sciences, 50(2), 179-193.

Henry, A. D., Ingold, K., Nohrstedt, D., \& Weible, C. M. (2014). Policy change in comparative contexts: Applying the advocacy coalition framework outside of Western Europe and North America. Journal of Comparative Policy Analysis: Research and Practice, 16(4), 299-312.

Hochstetler, K., \& Keck, M. E. (2007). Greening Brazil: Environmental activism in state and society. Durham, NC: Duke University Press.

Holmes, T., \& Scoones, I. (2001). Participatory environmental policy processes: experiences from North and South. In M. Pimbert \& T. Wakeford. (Eds.), PLA 40: Deliberative Democracy and Citizen Empowerment. International Institute of Environment and Empowerment. London, UK: International Institute for Environment and Development, Sustainable Agriculture Programme.

Hopwood, B., Mellor, M., \& O'Brien, G. (2005). Sustainable development: mapping different approaches. Sustainable development, 13(1), 38-52.

Hunter, W., \& Power, T. J. (2019). Bolsonaro and Brazil's Illiberal Backlash. Journal of Democracy, 30(1), 68-82.

Ianoni, M. (2017). Para uma abordagem ampliada das coalizões. Sinais Sociais, 11(33), 99-129.

Ingold, K., \& Leifeld, P. (2014). Structural and institutional determinants of influence reputation: A comparison of collaborative and adversarial policy 
networks in decision making and implementation. Journal of Public Administration Research and Theory, 26(1), 1-18.

Jenkins-Smith, H. C., Nohrstedt, D., Weible, C. M., \& Ingold, K. (2018). The advocacy coalition framework: An overview of the research program. In C. Weible \& P. Sabatier (Eds.), Theories of the policy process (Vol. 4, pp. 135-171). Boulder, CO: Routledge.

Jenkins-Smith, H. C., Nohrstedt, D., Weible, C. M., \& Sabatier, P. A. (2014). The advocacy coalition framework: Foundations, evolution, and ongoing research. In C. Weible \& P. Sabatier (Eds.), Theories of the policy process (Vol. 3, pp. 183-224). Boulder, CO: Routledge.

John, P. (2003). Is there life after policy streams, advocacy coalitions, and punctuations: Using evolutionary theory to explain policy change? Policy Studies Journal, 31(4), 481-498.

Kettell, S., \& Cairney, P. (2010). Taking the power of ideas seriously-the case of the United Kingdom's 2008 Human Fertilisation and Embryology Bill. Policy Studies, 31(3), 301-317.

Madeiro, C. (2019, October 24). Comissão do Senado vai apurar omissão do governo em relação a óleo no NE. UOL. Retrieved from https://noticias. uol.com.br/meio-ambiente/ultimas-noticias/ redacao/2019/10/24/comissao-do-senado-vaiapurar-omissao-do-governo-em-relacao-a-oleono-ne.htm

Marés, C., Moraes, M., \& Afonso, N. (2019, August 28). Salles erra ao dizer que seca causou aumento de queimadas na Amazônia. Lupa Piauí. Retrieved from https://piaui.folha.uol.com.br/lupa/2019/08/28/ salles-seca-queimadas-amazonia/

Mazui, G. (2019a, August 24). Bolsonaro diz que 'floresta não está pegando fogo', mas sim as áreas desmatadas. G1. Retrieved from https://g1.globo. com/politica/noticia/2019/08/24/bolsonaro-dizque-floresta-nao-esta-pegando-fogo-mas-sim-asareas-desmatadas.ghtml

Mazui, G. (2019b, August 21). Bolsonaro diz que ONGs podem estar por trás de queimadas na Amazônia para 'chamar atenção' contra o governo. G1. Retrieved from https://g1.globo.com/politica/ noticia/2019/08/21/bolsonaro-diz-que-ongs- podem-estar-por-tras-de-queimadas-na-amazoniapara-chamar-atencao-contra-o-governo.ghtml

McConnell, A., \& Hart, P. t. (2019). Inaction and public policy: understanding why policymakers 'do nothing. Policy Sciences, 52(4), 645-661.

Meeus, B. (2019). Politiques environnementales au Brésil: analyse historique et récents développements sous Jair Bolsonaro. La Pensee ecologique, 2, 45-61.

Mendes, K. (2019, September 28). Estudo indica que queimadas na Amazônia ocorreram em áreas desmatadas em 2019. El País. Retrieved from https://brasil.elpais.com/brasil/2019/09/26/ politica/1569456980_698387.html

Montpetit, É. (2011). Scientific credibility, disagreement, and error costs in 17 biotechnology policy subsystems. Policy Studies Journal, 39(3), 513-533.

Moreira, M. (2019, October 24). Salles usa imagem antiga para insinuar que Greenpeace seria culpado por óleo no NE. Folha de S. Paulo. Retrieved from https://www1.folha.uol.com.br/ambiente/2019/10/ salles-usa-imagem-antiga-para-insinuar-quegreenpeace-seria-culpado-por-oleo-no-ne.shtml

Moyson, S. (2017). Cognition and policy change: the consistency of policy learning in the advocacy coalition framework. Policy and Society, 36(2), 320-344.

Muta, J. (2019, October 25). 'Não é um ambientalista, é um impostor', diz Marina sobre Ricardo Salles. Folha de Pernambuco. Retrieved from https://folhape. com.br/politica/politica/oleo-no-litoral/2019/10/25/ BLG, 12926, 7, 1577, POLITICA, 2419-NAOAMBIENTALISTA-IMPOSTOR-DIZ-MARINASOBRE-RICARDO-SALLES.aspx

Nohrstedt, D., \& Weible, C. M. (2010). The logic of policy change after crisis: Proximity and subsystem interaction. Risk, Hazards \& Crisis in Public Policy, 1(2), 1-32.

O Globo. (2019). Fogo na Amazônia: o Brasil no centro de uma crise ambiental. Jornal $O$ Globo. Retrieved from https://www.youtube.com/ watch?v=B7wlxAu2j6k

Oliveira, E., \& Matos, T. (2020, April 13). Alertas de desmatamento na Amazônia batem recorde no primeiro trimestre de 2020, mostram dados do Inpe. G1. Retrieved from https://g1.globo.com/natureza/ noticia/2020/04/13/alertas-de-desmatamento- 
na-amazonia-crescem-5145percent-no-primeirotrimestre-mostram-dados-do-inpe.ghtml

Pádua, J. A. (2018). The Dilemma of the 'Splendid Cradle': Nature and Territory in the Construction of Brazil. In J. L. Soluri, C.; Pádua, J. A. (Ed.), A Living Past, Environmental Histories of Modern Latin America. New York, NY: Berghahn Books.

Pereira, C. (2019, February 14). As ONG’s não podem depender do governo. Istoé. Retrieved from https://istoe.com.br/as-ongs-nao-podem-dependerdo-governo/

Pierce, J. J., Peterson, H. L., \& Hicks, K. C. (2020). Policy change: an advocacy coalition framework perspective. Policy Studies Journal, 48(1), 64-86.

Prizibisczki, C. (2019, April 14). Governo institui anistia prévia a criminosos ambientais. OECO. Retrieved from https://www.oeco.org.br/ reportagens/governo-institui-anistia-previa-acriminosos-ambientais/

Pupo, A. (2019, October 30). Comissão especial aprova novo marco do saneamento que prevê atuação de empresas privadas. Estadão. Retrieved from https://economia.estadao.com.br/noticias/ geral,comissao-especial-aprova-novo-marco-desaneamento-que-preve-atuacao-de-empresasprivadas, 70003069955

Rochedo, P. R., Soares, B., Filho, Schaeffer, R., Viola, E., Szklo, A., Lucena, A. F. ... Rathmann, R. (2018). The threat of political bargaining to climate mitigation in Brazil. Nature Climate Change, 8(8), 695-698.

Sabatier, P. A. (1988). An advocacy coalition framework of policy change and the role of policyoriented learning therein. Policy Sciences, 21(2-3), 129-168.

Sabatier, P. A., Hunter, S., \& McLaughlin, S. (1987). The devil shift: Perceptions and misperceptions of opponents. Western Political Quarterly, 40(3), 449-476.

Sabatier, P. A., \& Jenkins-Smith, H. C. (1993). Policy change and learning: An advocacy coalition approach. Boulder, CO: Westview Press.

Sabatier, P. A., \& Jenkins-Smith, H. C. (1999). The Advocacy Coalition Framework: An Assessment. In P. A. Sabatier. (Ed.), Theories of the policy process (pp. 117-166). Boulder, CO: Westview Press.
Sabatier, P. A., \& Weible, C. M. (2007). The advocacy coalition framework: innovations and clarifications. In P. A. Sabatier (Ed.), Theories of the policy process (Vol. 2). Boulder, CO: Westview Press.

Shalders, A. (2019, September 12). Mudanças climáticas não são causadas pela ação humana, diz presidente de Comissão de Mudanças Climáticas do Congresso. BBC Brasil. Retrieved from https://www. bbc.com/portuguese/brasil-49683893

Soares, A. G. (2016). Atores e ideias na constituição do direito à Memória e à Verdade: análise da mudança política no Programa Nacional de Direitos Humanos. (Tese de Doutorado). Universidade Federal de São Carlos, São Carlos.

Soares, B., Filho, Rajão, R., Macedo, M., Carneiro, A., Costa, W., Coe, M. ... Alencar, A. (2014). Cracking Brazil's forest code. Science, 344(6182), 363-364.

Soares, I. (2019, May 29). Decreto de Bolsonaro reduz composição do Conama de 96 conselheiros para 23. Correio Braziliense. Retrieved from https://www.correiobraziliense.com.br/app/noticia/ politica/2019/05/29/interna_politica,758531/ decreto-de-bolsonaro-reduz-composicao-doconama-de-100-conselheiros-pa.shtml

Souza, \& Secchi, L. (2014). Política de Ciencia y Tecnología en Santa Catarina, Brasil: análisis a partir del modelo de coaliciones de defensa. Revista de Administração Pública, 48(4), 939-960.

Souza, J. (2004). A gramática social da desigualdade brasileira. Revista brasileira de ciências sociais, 19(54), 79-96.

Spring, J. (2020a, February 27). Brazil Environment Ministry fires top climate change officials. Reuters. Retrieved from https://uk.reuters.com/article/ uk-brazil-environment-climatechange/brazilenvironment-ministry-fires-top-climate-changeofficials-idUKKCN20L2A6?il=0

Spring, J. (2020b, April 06). Brazil minister fires analyst who opposed unauthorized wood exports. Reuters. Retrieved from https://www.reuters.com/ article/us-brazil-environment/brazil-minister-firesanalyst-who-opposed-unauthorized-wood-exportsidUSKBN21O30F

Toledo, M. (2019, August 20). Salles diz que relacionar céu escuro em SP a queimadas na Amazônia é fake news. Folha de S. Paulo. Retrieved from https:// 
www1.folha.uol.com.br/ambiente/2019/08/sallesdiz-que-relacionar-ceu-escuro-em-sp-a-queimadasna-amazonia-e-fake-news.shtml

Trigueiro, A. (2019, May 15). Financiadores internacionais desaprovam anúncio de ministro sobre 'irregularidades' no Fundo Amazônia. G1. Retrieved from https://g1.globo.com/natureza/ blog/andre-trigueiro/post/2019/05/17/critica-deministro-contraria-parceiros-que-financiam-ofundo-amazonia.ghtml

Turollo, R., Jr., \& Fernandes, T. (2019, August 24). Governo federal cobra participação dos estados no combate ao fogo na Amazônia. Folha de S. Paulo. Retrieved from https://www1.folha.uol. com.br/ambiente/2019/08/governo-federal-cobraparticipacao-dos-estados-no-combate-ao-fogo-naamazonia.shtml

TV Cultura. (2019). Entrevista com Ministro do Meio Ambiente - Ricardo Salles.

Valor Online. (2019, October 29). Volume de óleo no Nordeste é semelhante ao vazamento no Golfo do México, diz presidente da Petrobras. G1. Retrieved from https://g1.globo.com/natureza/desastreambiental-petroleo-praias/noticia/2019/10/29/ volume-de-oleo-no-nordeste-e-semelhante-aovazamento-no-golfo-do-mexico-diz-presidente-dapetrobras.ghtml

Vick, M. (2019, April 10). Qual o plano do governo para a concessão de parques nacionais? Nexo Jornal. Retrieved from https://www.nexojornal.com.br/ expresso/2019/04/10/Qual-o-plano-do-governopara-a-concessão-de-parques-nacionais

Vieira, R. (2019, August 17). Discurso antiambientalista de Bolsonaro preocupa empresários do agronegócio. O Globo. Retrieved from https://oglobo.globo.com/sociedade/ discurso-antiambientalista-de-bolsonaro-preocupaempresarios-do-agronegocio-23884165

Vilela, P. R. (2019, April 17). Bolsonaro defende mineração e agropecuária em terras indígenas. Agência Brasil. Retrieved from http://agenciabrasil. ebc.com.br/politica/noticia/2019-04/bolsonarodefende-mineracao-e-agropecuaria-em-terrasindigenas

Viola, E., \& Franchini, M. (2017). Brazil and climate change: beyond the Amazon: Routledge.

Vivas, F. (2019, November 18). Maia cria CPI para investigar origem do óleo que atinge praias do Nordeste. G1. Retrieved from https://g1.globo.com/ politica/noticia/2019/11/18/maia-cria-cpi-parainvestigar-origem-do-vazamento-de-oleo-queatinge-praias-do-nordeste.ghtml

Watkins, M., \& Rosegrant, S. (1996). Sources of power in coalition building. Negotiation journal, 12(1), 47-68.

Weible, C. M., Ingold, K., Nohrstedt, D., Henry, A. D., \& Jenkins-Smith, H. C. (2019). Sharpening advocacy coalitions. Policy Studies Journal, Early View. Retrieved from https://doi.org/10.1111/ psj. 12360

Weible, C. M., \& Heikkila, T. (2017). Policy conflict framework. Policy Sciences, 50(1), 23-40.

Weible, C. M., \& Ingold, K. (2018). Why advocacy coalitions matter and practical insights about them. Policy \& politics, 46(2), 325-343.

Weible, C. M., Heikkila, T., Ingold, K., \& Fischer, M. (2016). Policy debates on hydraulic fracturing: comparing coalition politics in North America and Europe. New York, NY: Springer.

Weible, C. M., Heikkila, T., \& Pierce, J. (2018). Understanding rationales for collaboration in highintensity policy conflicts. Journal of Public Policy, $38(1), 1-25$.

Weible, C. M., \& Sabatier, P. A. (2009). Coalitions, science, and belief change: Comparing adversarial and collaborative policy subsystems. Policy Studies Journal, 37(2), 195-212.

Weible, C. M., Sabatier, P. A., \& McQueen, K. (2009). Themes and variations: Taking stock of the advocacy coalition framework. Policy Studies Journal, 37(1), 121-140. 
RAP | Large-scale environmental policy change: analysis of the Brazilian reality

\section{Mauro Guilherme Maidana Capelari}

https://orcid.org/0000-0002-1259-9909

Ph.D. in Public Administration and Public Policy; Adjunct Professor in Center for Sustainable Development at UnB. E-mail: capelari.unb@gmail.com

\section{Suely Mara Vaz Guimarães de Araújo}

https://orcid.org/0000-0003-2363-771X

Ph.D. in Political Science; Professor in Braziliense Institute of Public Law and Institute of Political Science at

UnB. E-mail: suelymvg@gmail.com

\section{Paulo Carlos Du Pin Calmon}

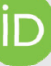

https://orcid.org/0000-0001-6314-9564

Ph.D. in Political Science; Associate Professor in Institute of Political Science at UnB.

E-mail: paulo.calmon@gmail.com

\section{Benilson Borinelli}

https://orcid.org/0000-0002-7256-7618

Ph.D. in Social Science; Associate Professor in Department of Administration at UEL. E-mail: benilson@uel.br 